\title{
Potentially toxic epiphytic dinoflagellate assemblages on macroalgae in the NW Mediterranean
}

\author{
Magda Vila*, Esther Garcés, Mercedes Masó \\ Institut de Ciències del Mar, Passeig Marítim de la Barceloneta, 37-49, 08003 Barcelona, Catalonia, Spain
}

\begin{abstract}
A potentially toxic epiphytic dinoflagellate assemblage on macroalgae was studied for 1 yr in a shallow protected rocky habitat in Palamós (Costa Brava, NW Mediterranean). The assemblage was monitored on 4 macroalgae: Corallina elongata (Rhodophyceae), Dictyota dichotoma, Dilophus fasciola and Halopteris scoparia (Phaeophyceae). The dominant dinoflagellates were Ostreopsis sp., and the accompanying species were Coolia monotis and Prorocentrum lima. The diatom Coscinodiscus sp. was an abundant component of the assemblage. Ostreopsis followed the same seasonal pattern on the 4 macroalgae selected. Substrate was not significantly different for the dinoflagellate assemblages. Ostreopsis was present both in the water column and in the sand concomitant with maximal cell densities on macroalgae. Small-scale sampling revealed that all the epiphytic organisms prefer slightly shaken habitats. While Ostreopsis sp. prefers shaken to slightly shaken waters, Coolia monotis prefers slightly shaken to calm ones. The dinoflagellate assemblage follows a clear seasonal pattern, achieving maximum cell concentration during spring and summer without significant relative changes in the species composition. The epiphytic assemblage was widespread along the Catalan coast and Majorca, although dinoflagellates were found to be more abundant in the Costa Brava. In Corsica, diatoms dominated the assemblage, whereas Ostreopsis sp. was a minor component.
\end{abstract}

KEY WORDS: Ostreopsis · Coolia monotis · Prorocentrum lima $\cdot$ Benthic dinoflagellates · Ciguatera fish poisoning

Resale or republication not permitted without written consent of the publisher

\section{INTRODUCTION}

Epiphytic (in close association with macroalgae) and benthic (in coral rubble, sand and detritus) dinoflagellates are relevant because the species Gambierdiscus toxicus causes ciguatera (Yasumoto et al. 1977, Adachi \& Fukuyo 1979). Ciguatera, or ciguatera fish poisoning, is a human disease caused by the ingestion of contaminated marine finfish from tropical and subtropical regions, which results in gastrointestinal and neurological disorders and sometimes death. Polyether toxins (ciguatoxins and maitotoxins, among others) that are produced by marine epiphytic dinoflagellates (Steidinger 1983) may cause these symptoms. Macroalgae (and epiphytic assemblages of harmful dinofla-

*E-mail: magda@icm.csic.es gellates) are eaten by herbivorous fish, which then become toxic. Thus, the toxins are biologically concentrated within the food chain (Steidinger \& Baden 1984). A dinoflagellate assemblage in the genera Gambierdiscus, Ostreopsis, Coolia, Prorocentrum and Amphidinium (Ballantine et al. 1985, Carlson \& Tindall 1985, Bomber \& Aikman 1989, Bourdeau et al. 1995, Faust 1995) has also been reported in ciguateraendemic areas. In particular, Prorocentrum lima, $P$. concavum, Ostreopsis siamensis and O. ovata have been implicated in ciguatera fish poisoning based on distribution, toxicity to mice and the presence of a fatsoluble toxic fraction (Yasumoto et al. 1980, Nakajima et al. 1981). These organisms form epiphytic communities associated with coral reefs, or rather with macroalgae attached to coral surfaces. These assemblages may vary in species composition and cell concentration 
between sites (Tindall \& Morton 1998). The mixed association of toxic dinoflagellates may contribute to the polymorphism of the clinical features of ciguatera (Yasumoto et al. 1987).

Ostreopsidaceae species are widespread in most epiphytic and benthic dinoflagellate communities from ciguatera-endemic regions of the world $\left(35^{\circ} \mathrm{N}\right.$ to $\left.35^{\circ} \mathrm{S}\right)$. Thus, the geographic distribution of Ostreopsis siamensis, O. lenticularis and O. ovata is similar to that of Gambierdiscus toxicus (Tindall \& Morton 1998), with 2 notable exceptions: $O$. siamensis and $O$. ovata have been reported in the Mediterranean Sea (Taylor 1979, Tognetto et al. 1995). Nevertheless, data are limited on the incidence of Ostreopsis in the waters of the Mediterranean Sea and on the magnitude of potentially toxic epiphytic dinoflagellate assemblage attached to macroalgae.

In this study, we quantified epiphytic dinoflagellate assemblages on the Catalan coast, NW Mediterranean. The potentially toxic epiphytic dinoflagellate assemblage associated with macroalgae was examined during an annual cycle in a rocky habitat. In addition, small-scale spatial variability and middle-scale spatial distribution were analysed to shed some light on the epiphytic dinoflagellate assemblages in the NW Mediterranean.

The dominant dinoflagellate Ostreopsis sp. could not be assigned to any described species. Thus, a brief description of the species with scanning electron microphotographs is included for further considerations.

\section{MATERIAL AND METHODS}

Sampling sites. Epiphytic dinoflagellates on selected macroalgae (Rhodophyceae and Phaeophyceae) were quantified for 1 yr (July 1997 to July 1998). The sampled macroalgae grow in multispecies assemblages attached to stones in the infralittoral. Macroalgal specimens (in triplicate) were collected weekly at 20 to $40 \mathrm{~cm}$ depths during summer (July and August 1997) and monthly during the rest of the year. The sampling site was a shallow protected rocky habitat in Palamós (Catalan sea, NW Mediterranean). During the summers of 1997 and 1998, a more extensive study was carried out. Fourteen stations were sampled, mainly along the Costa Brava (northern Catalan coast) and in 2 other Mediterranean areas (Majorca and Corsica) (Fig. 1).

Sampling methods. A subsample (15 to $20 \mathrm{~g}$ fresh weight [FW]) was carefully cut and placed with tweezers in a small glass bottle containing $10 \mathrm{ml}$ of formaldehyde-filtered seawater. Since the macroalgae community is dynamic and the species composition varies throughout the year, at every sampling date the available macroalgae were taken to cover the annual cycle.

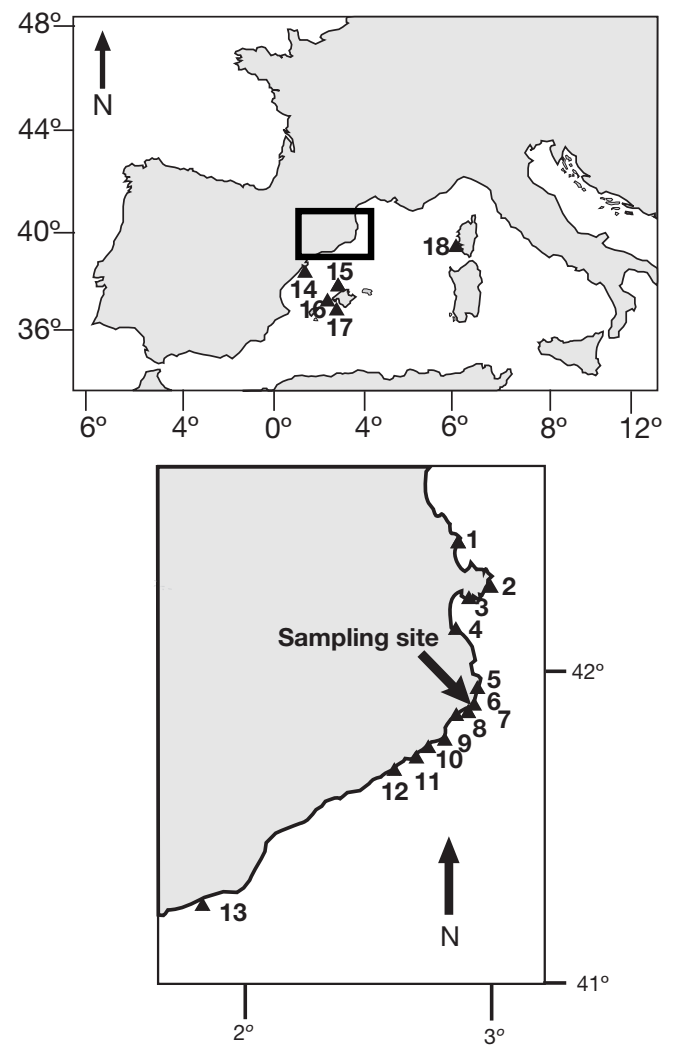

Fig. 1. Study area and stations sampled. 1: Cala Garbet; 2: Portlligat; 3: Canyelles Grosses; 4: Cala Portitxol; 5: Cala Pedrosa; 6: La Foradada; 7: Palamós (sampling site); 8: Gran de Palamós; 9: Cala Canyet; 10: Santa Cristina d'Aro; 11: El Xuclador; 12: Sant Pol de Mar; 13: Vallcarca; 14: Riu Sènia; 15: Deià; 16: Cala Fornells; 17: Portals Vells; 18: Campomoro; 1-14 in Catalonia; 15-17 in Majorca; 18 in Corsica

The main macroalgae analysed were Corallina elongata (Rhodophyceae), Dictyota dichotoma, Dilophus fasciola and Halopteris scoparia (Phaeophyceae). C. elongata is present throughout the year; thus, we have studied the seasonal patterns in this macroalga. In addition, other macroalgae were collected sporadically, mainly during the cold season, when the 4 target species were very scarce. The additional macroalgae sampled were Jania corniculata, Pterocladia capillacea, Laurencia gr. obtusa, Rissoella verruculosa, Ceramium ciliatum, Peyssonnelia squamaria (Rhodophyceae), Dictyopteris membranacea, Padina pavonica (Phaeophyceae) and Ulva sp. (Chlorophyceae). Surface water $(0.5 \mathrm{~m})$ and sediment samples were collected in 150 and $50 \mathrm{ml}$ bottles and preserved with formaldehyde ( $1 \%$ final concentration) for dinoflagellate examination. Nutrient samples were taken and frozen immediately and analysed for nitrate, nitrite, ammonia, phosphate and silicate as described by Grasshoff et al. (1983). Temperature and salinity were measured. 
Once in the laboratory, macroalgae bottles were shaken vigorously for 1 min to dislodge the epiphytic organisms. Macroalgae were removed and the sample was settled for $6 \mathrm{~h}$ in $10 \mathrm{ml}$ counting chambers. An appropriate area of the chamber was then scanned (Throndsen 1995) for epiphytic organism counting at 63 to $200 \times$ magnification using a Leica-Leitz DM-IL inverted microscope (Leica Mikroskopie und Systeme $\mathrm{GmbH}$, Wetzlar). Samples were examined and counted for epiphytic microalgal species. When high densities of organisms were found in the sample, only a subsample was examined. Macroalgae were processed for fresh weight (FW) and dry weight (DW) measurements. DW was measured after the macroalgae were dried in an oven at $60^{\circ} \mathrm{C}$. FW and DW were highly correlated (regression analysis, $\mathrm{r}^{2}>0.98$ ). Thus, we worked with FW, as is usual in other studies. One-way ANOVA was performed to test differences between the 4 macroalgae for each epiphyte dinoflagellate $(4 \times 4)$ (STATISTICA for Windows, Statsoft, Tulsa, OK). The analysis was done during the warmer months to avoid seasonal interactions. Water samples for phytoplankton quantification were settled for $24 \mathrm{~h}$ in $50 \mathrm{ml}$ counting chambers and they were then examined as above. Sediment samples (around $30 \mathrm{~g}$ ) were sonicated in filtered seawater for 10 to $15 \mathrm{~s}$ and sieved. The 20 to $135 \mu \mathrm{m}$ fraction was examined in an inverted microscope, as described above.

In April 1998, small-scale samples were taken at Stn 7 to study the spatial variability of epiphytic organisms on Corallina elongata in relation to hydrodynamism. Three hydrodynamic regimens were defined: shaken, slightly shaken and calm. Shaken regimens were observed in sites where macroalgae were directly hit by waves (high hydrodynamism); calm regimens corresponded to sites where macroalgae were protected from the waves by rock barriers (low hydrodynamism); and the slightly shaken regimens were intermediate. Macroalgal samples were collected from the 3 habitats and processed as described above. Three sites were sampled at each habitat and 3 replicates were analysed. An ANOVA nested design was used $(3 \times 3 \times 3)$ (STATISTICA for Windows).

During summer 1997 and 1998, 14 stations were sampled, mainly along the Costa Brava (northern region of the Catalan coast, Fig. 1) to limit the geographical distribution. Samples were also taken from Corsica (summer 1998) and Majorca (Balearic Islands, summer 2000) and qualitatively examined for the epiphytic assemblage to determine the extent of the phenomenon in the NW Mediterranean.

Identification of dinoflagellates. Samples were fixed with $4 \%$ glutaraldehyde for scanning electron microscopy. One millilitre of fixed sample was filtered through a $13 \mathrm{~mm}$ diameter and $0.8 \mu \mathrm{m}$ pore size Nucle- pore PC polycarbonate membrane filter (Costar, Europe Ltd, Badhoevedorp). Samples were washed in distilled water and dehydrated in an ethanol series (30, $50,70,80,90,100 \%$ ) at $4^{\circ} \mathrm{C}$, critical point dried with $\mathrm{CO}_{2}$ and examined under a Hitachi S-570 scanning electron microscope (Nissei Sangyo Co. Ltd, Tokyo; modified from Faust et al. 1996).

\section{RESULTS}

\section{Taxonomy of the epiphytic assemblages}

Natural populations of benthic dinoflagellates and diatoms formed a mucilaginous matrix on the macroalgal thallus and aggregated therein (Fig. 2A,B). Cells remained motile within the matrix and loosely linked to macroalgae, as revealed by light microscopy. When the epiphyte assemblage was dense, the brownish mucilaginous matrix covering the surface of the algae was visible to the naked eye.

The dinoflagellate epiphyte assemblage on macroalgae comprised Coolia monotis, Prorocentrum lima and especially Ostreopsis sp. The highest Ostreopsis sp. concentration was $596 \times 10^{3}$ cells g $^{-1} \mathrm{FW}$ macroalga on Halopteris scoparia in July 1997, or $6270 \times 10^{3}$ cells g $^{-1}$ DW macroalgae. $P$. mexicanum and $P$. emerginatum were occasionally recorded as minor components of the community. The benthic diatom Coscinodiscus sp. was an abundant constituent, sometimes accompanied by other diatoms such as Striatella sp. and Cylindrotheca closterium. Polychaete and crustacean larvae were often observed.

The morphological features of the dominant species, Ostreopsis sp., do not match those described elsewhere (Fukuyo 1981, Norris et al. 1985, Quod 1994, Faust \& Morton 1995, Faust et al. 1996, Faust 1999). Ostreopsis cells were usually quite large, pointed towards the sulcus in apical view and compressed anteroposteriorly (about $22 \mu \mathrm{m}$ ). The dorsoventral diameter (length) was 63 to $90 \mu \mathrm{m}$ (average $75 \mu \mathrm{m}$ ) and the transdiameter (width) 34 to $56 \mu \mathrm{m}$ (average $45 \mu \mathrm{m}$ ) (Fig. $2 \mathrm{C}, \mathrm{D}, \mathrm{E})$. The pore plate (Po) was about $10 \mu \mathrm{m}$ long. On the epitheca, the $1^{\prime}$ plate was large and in contact with plates $\mathrm{Po} / 2^{\prime}, 3^{\prime}, 1^{\prime \prime}, 2^{\prime \prime}, 6^{\prime \prime}$ and $7^{\prime \prime}$. The external part of the thecal plates was covered with 1 size of pores ( 0.1 to $0.2 \mu \mathrm{m}$ diameter).

There may be confusion in the literature about the morphology of Ostreopsis siamensis and O. lenticularis. O. siamensis, which was first described by Schmidt (1902), was redescribed by Fukuyo (1981), when he also described $O$. lenticularis and $O$. ovata. $O$. siamensis and $O$. lenticularis were similar in size but differed in the presence of dissimilar thecal pore sizes. $O$. siamensis was found to have 1 size of thecal pore 


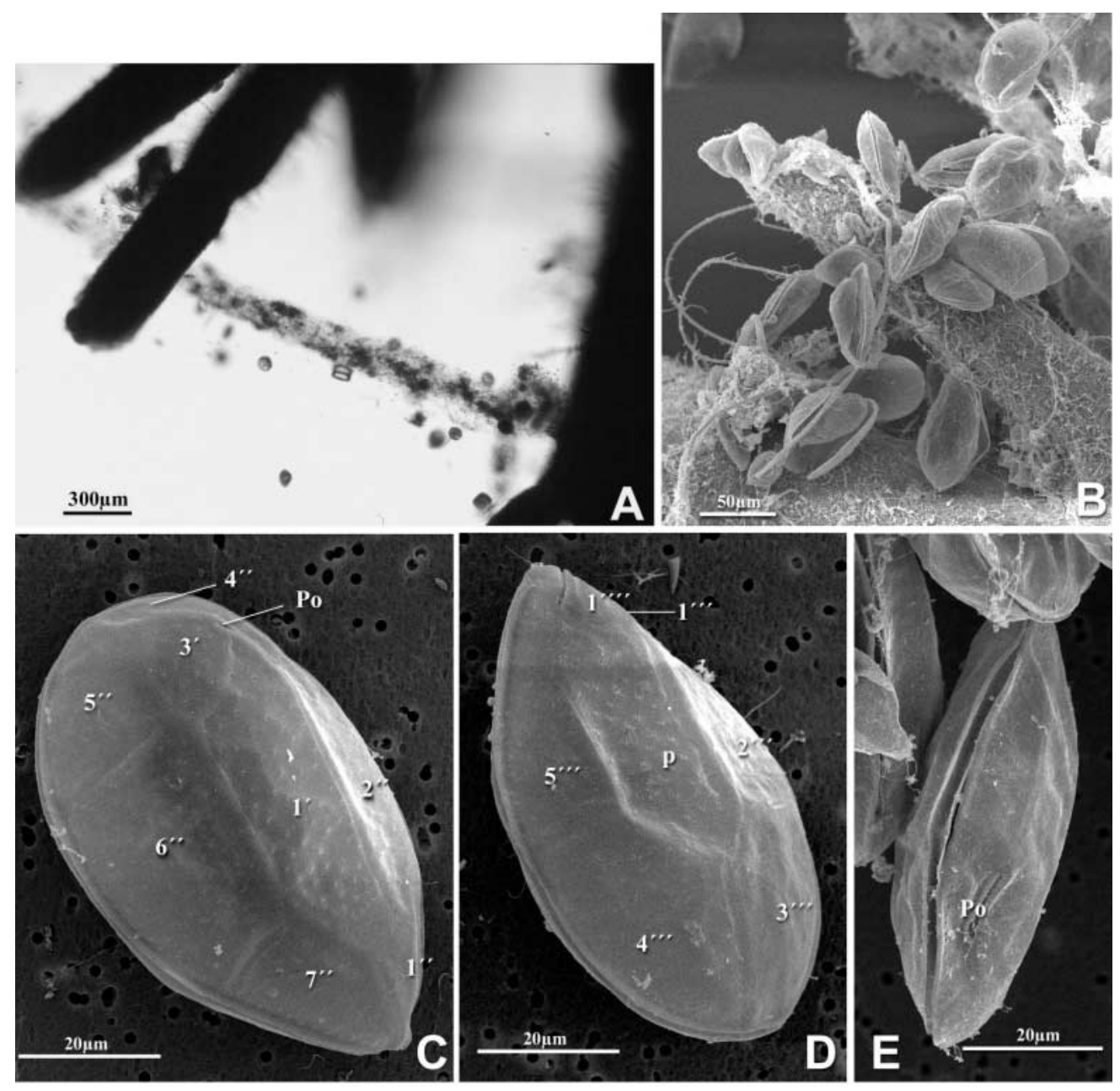

Fig. 2. Mucilaginous matrix of epiphytic dinoflagellates on a macroalga observed under (A) light microscope and (B) scanning electron microscope (SEM). Ostreopsis sp. cells viewed with SEM in (C) epithecal view, (D) hypothecal view and (E) left lateral view

whereas O. lenticularis had 2 sizes (Fukuyo 1981). O. ovata was smaller and had 1 size of thecal pores. In contast, Faust et al. (1996) found that O. siamensis was bigger than $O$. lenticularis and had 2 sizes of thecal pores, while $O$. lenticularis had 1 pore size. Our species description agrees with the $O$. siamensis (in cell size and number of pore sizes) described by Fukuyo (1981), but not with that described by Faust et al. (1996). It also agrees with O. ovata in the number of pore sizes, although this organism is smaller than our species. Thus, given the confusion, it was not assigned any specific name. Taxonomical studies and genetic assays are in progress (A. Penna in press).

\section{Preferred habitat and seasonal variability}

The temporal variability in the physico-chemical characteristics of the study site ( $\operatorname{Stn} 7$ ) is shown in Fig. 3A. Water temperature showed marked seasonal- ity (range 11.5 to $26.3^{\circ} \mathrm{C}$ ). The study site received, during periods of rain, freshwater from a small river. Accordingly, salinity oscillated between 37.2 and $38.1 \mathrm{psu}$. Nutrient concentrations ranged from 0.11 to $0.86 \mu \mathrm{M}$ for phospate, 0.76 to $7.74 \mu \mathrm{M}$ for DIN and 0.17 to $4.51 \mu \mathrm{M}$ for silicate. A clear temporal variation was not observed. However, discrete high concentrations of DIN and silicate were observed during winter and spring.

The concentration of Ostreopsis sp. in 3 habitats (attached on macroalgae, in the water column and in sand) at Stn 7 is shown in Fig. 3B. Ostreopsis sp. was also the dominant species in the water column and sand. The 3 habitats showed a clear seasonal pattern, with high biomass from late winter until late summer. Ostreopsis sp. in the water column achieved high cell concentrations $\left(>10^{4}\right.$ cells $\mathrm{l}^{-1}$ ) concomitant with maximal cell densities on macroalgae $\left(10^{4}\right.$ to $10^{5}$ cells $\mathrm{g}^{-1}$ FW). Cell densities in the water column and on macroalgae were positively and significantly corre- 

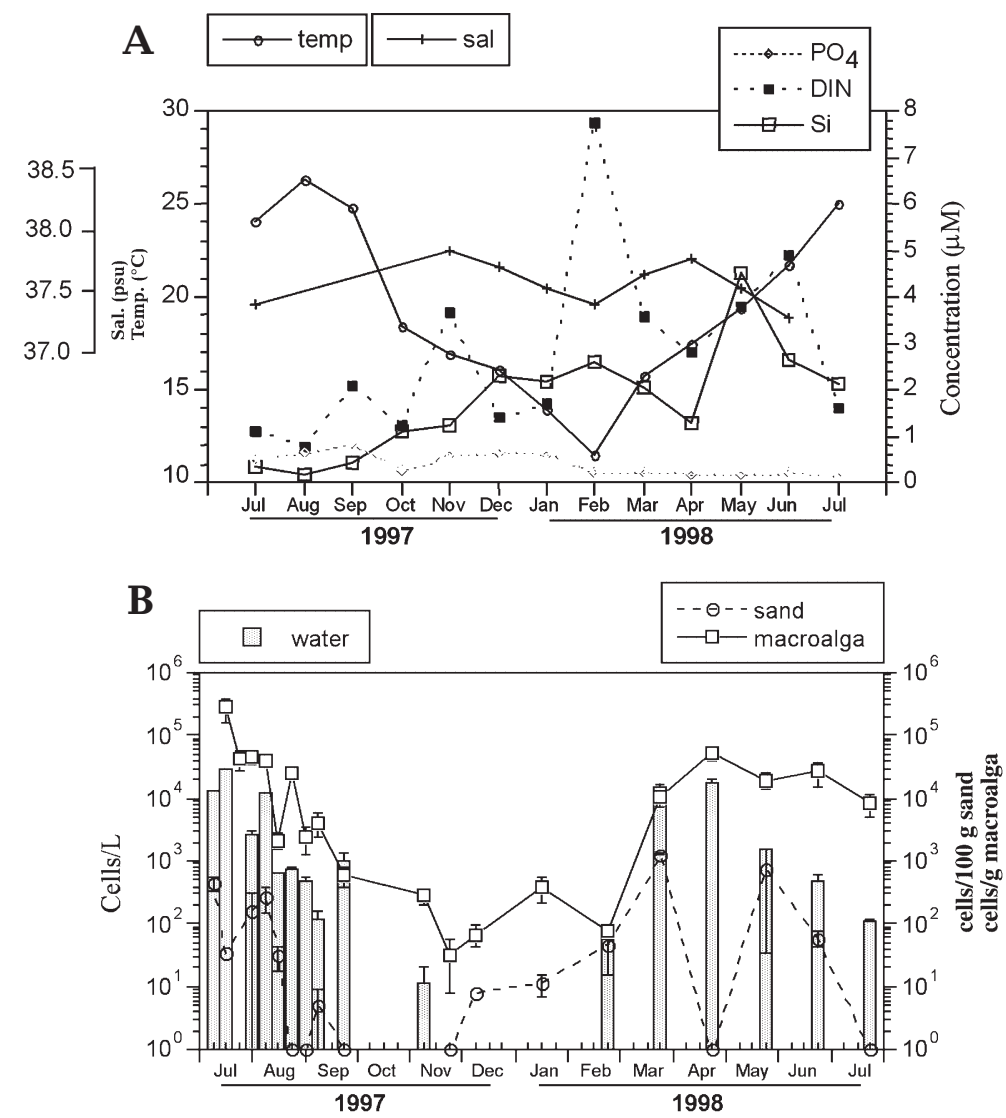

Fig. 3. (A) Temporal physico-chemical properties of the study area. Nutrient samples from July to September 1997 were taken approximately $200 \mathrm{~m}$ away from the sampling site. Sal: salinity; Temp: temperature. (B) Seasonal abundance of Ostreopsis sp. in the macroalgae, in the water column and on the sediment at the sampling site. Cells on macroalgae are the averaged values for the 4 macroalgae sampled. Bars indicate SE. Missing bars correspond to macroalgae that were not sampled. FW: fresh weight lated ( $\mathrm{n}=18$, Pearson's $\mathrm{r}=0.82, \mathrm{p}<0.001)$, especially for Corallina elongata $(n=11$, Pearson's $r=$ $0.79, \mathrm{p}<0.05)$ and Halopteris scoparia ( $\mathrm{n}=8$, Pearson's $r=0.91, p<0.05)$. Cell densities in sand followed the same seasonal pattern (although this was not statistically significant, since we worked near the detection limit) as in the water column and on macroalgae. There were few Coolia monotis and Prorocentrum lima in the water column (maximum cell concentrations 4600 and 330 cells $\mathrm{l}^{-1}$, respectively) and they were mostly absent from sand, except on some sampling days (cell concentrations $<2$ cells $\mathrm{g}^{-1}$ ).

Ostreopsis followed the same seasonal pattern on the 4 substrates selected (Corallina elongata, Dictyota dichotoma, Dilophus fasciola and Halopteris scoparia) (Fig. 4A). Maximum concentrations were found from March to September. Substrate (macroalgae) was not significant (ANOVA, p > 0.05) for Ostreopsis sp., Prorocentrum lima and Coolia monotis, but was significant for Cocinodiscus sp. (ANOVA, p < 0.05). The analysis was performed during the warmest months to avoid seasonal interactions. Table 1 presents the epiphytic dinoflagellates on additional macroalgal species examined all year round. The epiphytic assemblage of dinoflagellates was the same, with Ostreopsis sp. the most abundant species Coscinodiscus also reached high cell numbers (Table 1).

The distribution of potentially toxic epiphytic dinoflagellate and Coscinodiscus assemblages on Corallina elongata (Ostreopsis sp., Coolia monotis, Prorocentrum lima and Coscinodiscus sp.) and monthly relative species abundance are shown in

Table 1. Epiphytic assemblage composition in macroalgae (other than 4 target species) from the sampling site (Palamós) year round. Average epiphytic cell concentration on macroalgae (cells $\mathrm{g}^{-1}$ fresh weight [FW]) and relative abundance (\%). Os: Ostreopsis sp.; Co: Coolia monotis; Pl: Prorocentrum lima; Cs: Coscinodiscus sp.

\begin{tabular}{|c|c|c|c|c|c|c|c|c|c|c|}
\hline \multirow[t]{2}{*}{ Macroalgae } & \multirow[t]{2}{*}{ Season } & \multirow[t]{2}{*}{$\mathrm{n}$} & \multicolumn{4}{|c|}{ Average (cells g ${ }^{-1} \mathrm{FW}$ ) } & \multicolumn{4}{|c|}{ Relative abundance (\%) } \\
\hline & & & Os & Co & $\mathrm{Pl}$ & $\mathrm{Cs}$ & Os & Co & $\mathrm{Pl}$ & Cs \\
\hline Pterocladia capillacea & Summer & 2 & 2591 & 90 & 647 & 3574 & 38 & 1 & 9 & 52 \\
\hline Jania corniculata & & 1 & 1181 & 47 & 331 & 189 & 68 & 3 & 19 & 11 \\
\hline Laurencia gr. obtusa & Autumn & 2 & 867 & 0 & 397 & 785 & 42 & 0 & 19 & 38 \\
\hline Laurencia gr. obtusa & & 3 & 1410 & 4 & 35 & 16 & 96 & 0 & 2 & 1 \\
\hline Pterocladia capillacea & Winter & 4 & 156 & 0 & 1 & 0 & 99 & 0 & 1 & 0 \\
\hline Ulva sp. & & 1 & 109 & 0 & 5 & 34 & 74 & 0 & 4 & 23 \\
\hline Risoella verruculosa & & 1 & 0 & 0 & 0 & 0 & & & & \\
\hline Jania corniculata & & 4 & 242 & 5 & 2 & 124 & 65 & 1 & 0 & 33 \\
\hline Pterocladia capillacea & & 3 & 133 & 1 & 1 & 39 & 76 & 1 & 1 & 23 \\
\hline Ceramium ciliatum & Spring & 3 & 74147 & 4681 & 55 & 11190 & 82 & 5 & 0 & 12 \\
\hline Dictyopteris membranacea & & 3 & 47976 & 9557 & 238 & 16529 & 65 & 13 & 0 & 22 \\
\hline Laurencia gr. obtusa & & 3 & 134512 & 11801 & 130 & 6740 & 88 & 8 & 0 & 4 \\
\hline Peyssonnelia squamaria & & 3 & 4209 & 1030 & 46 & 2354 & 55 & 13 & 1 & 31 \\
\hline Padina pavonica & & 2 & 56404 & 33825 & 481 & 25475 & 49 & 29 & 0 & 22 \\
\hline
\end{tabular}


A
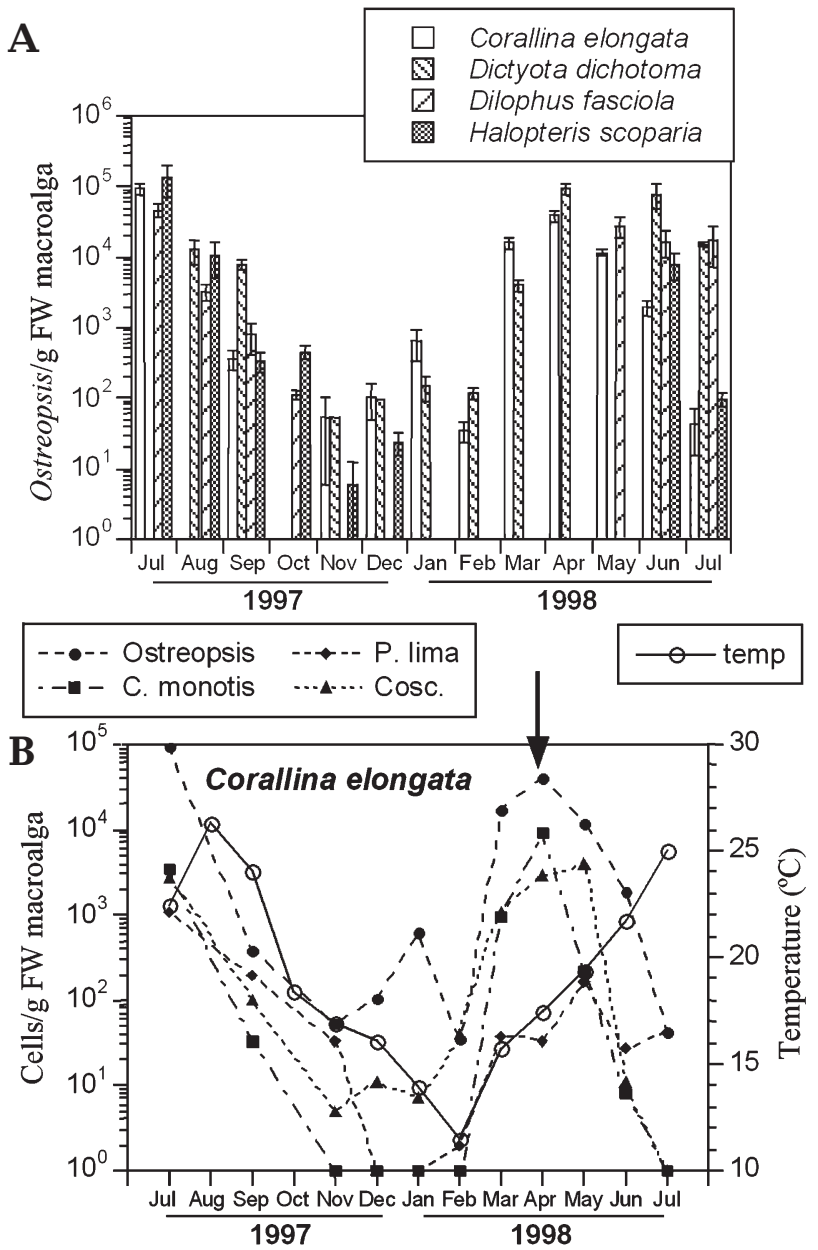

C

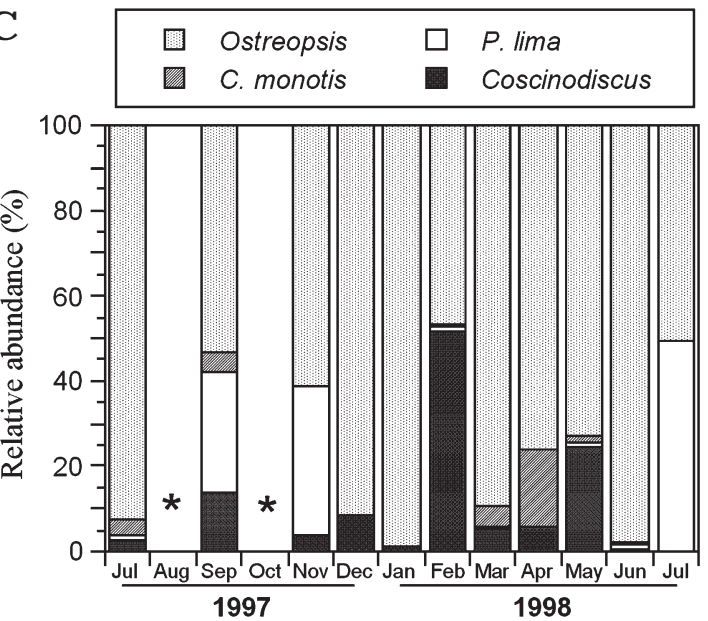

Fig. 4. (A) Seasonal abundance of epiphyte Ostreopsis sp. on the 4 macroalgae: Corallina elongata, Dictyota dichotoma, Dilophus fasciola and Halopteris scoparia. (B) Seasonal abundance and $(\mathrm{C})$ percentage of the major epiphytic organisms (Ostreopsis sp., C. monotis, P. lima and Coscinodiscus sp.) on C. elongata from July 1997 to July 1998. Asterisks indicate the months in which the macroalgae were not collected. Arrow indicates the day on which sampling was intensive to record the spatial variability associated with 3 hydrodynamic regimens
Fig. 4B and C, respectively. The 4 epiphytic species followed the same seasonal pattern $(\mathrm{n}=34$, Pearson's $\mathrm{r}=$ 0.87, $\mathrm{p}<0.05$ ). Although Ostreopsis sp. was the most dominant species, the relative abundances varied (Fig. 4C). For instance, in April C. monotis achieved $18 \%$ relative abundance in $C$. elongata, whereas it reached $64 \%$ in the other substrate, Dictyota dichotoma (absolute abundance of $143 \times 10^{3}$ cells g $^{-1}$ FW). P. lima occasionally achieved high relative abundance (28 to $49 \%$ ), which does not reflect high cell densities $\left(<200\right.$ cells $P$. lima $\left.\mathrm{g}^{-1} \mathrm{FW}\right)$. On the contrary, it is caused by low densities on the whole epiphytic community (80 to 700 cells $\mathrm{g}^{-1} \mathrm{FW}$ ).

The spatial variability of the epiphytic assemblage on Corallina elongata is shown in Fig. 5 (April 1998). The photophilic communities of $C$. elongata are typical of shaken or turbulent environments. In the area sampled, macroalgae were scarce in the calm area (where fine sandy deposition was observed) and abundant in slightly shaken or shaken areas. Cell densities of all epiphytic organisms were the highest in slightly shaken sites. The dominant species were Ostreopsis sp. and Coolia monotis, whereas cell densities on Coscinodiscus sp. $\left(<10^{4}\right.$ cells $\left.\mathrm{g}^{-1} \mathrm{FW}\right)$ and Prorocentrum lima were very low $\left(<10^{2}\right.$ cells $\left.\mathrm{g}^{-1} \mathrm{FW}\right)$. Ostreopsis sp. was more abundant than C. monotis in shaken sites (75 vs $19 \%$ ) and less abundant in calm sites (8 vs $81 \%$ ). In slightly shaken sites, the preferred habitat for Ostreopsis sp. and C. monotis, they were co-dominant (41 vs 51\%) (Fig. 5). Differences among the 3 regimens (shaken, slightly shaken and calm) were significant (ANOVA, $\mathrm{p}<0.05$ ), but those within groups (3 sites, 3 replicates) were not significant (ANOVA, p > 0.05).

Cell abundances are shown from the broader sampling area along Costa Brava in Table 2. The epi-

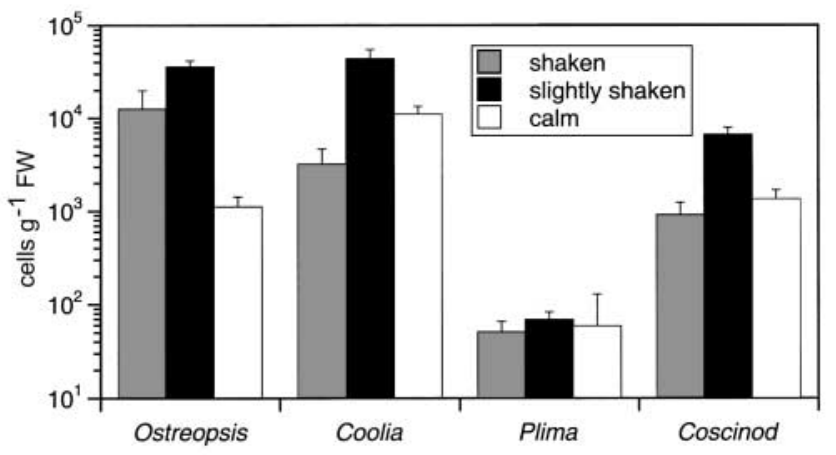

Fig 5. Epiphytic averaged densities (Ostreopsis sp., Coolia monotis, Prorocentrum lima and Coscinodiscus) on Corallina elongata in 3 hydrodynamic regimens (shaken, slightly shaken and calm). Samples were taken in the sampling station in April 1998 (when cell densities where high, see arrow in Fig 4B) 
phytic assemblage (4 microalgal species enumerated) is shown on various macroalgae. Dinoflagellates were most abundant at Stns 6 to 11 (which are the nearest to the sampled site; Fig. 1). A similar assemblage (on the fourth main species) was found in Majorca, in contrast with Corsica, where diatoms dominated the community and Ostreopsis sp. was a minor component.

\section{DISCUSSION}

\section{The epiphytic dinoflagellate assemblage in the Mediterranean: comparison with other places}

This is not the first report of the genus Ostreopsis in the Mediterranean Sea. Taylor (1979) described an association of Ostreopsis siamensis, Coolia monotis,

Table 2. Epiphytic assemblage composition in macroalgae from other stations in the NW Mediterranean. Average epiphytic cell concentration on macroalgae (cells g ${ }^{-1} \mathrm{FW}$ ) and relative abundance $(\%)$. See Table 1 for species abbreviations. -: absent; +: present $_{i}++$ : low abundance; +++ : high abundance; ++++ : very high abundance. ${ }^{*}$ Diatoms other than Coscinodiscus

\begin{tabular}{|c|c|c|c|c|c|c|c|c|c|}
\hline \multirow[t]{2}{*}{ Macroalgae } & \multirow[t]{2}{*}{ Stn } & \multicolumn{4}{|c|}{ Abundance (cells g ${ }^{-1} \mathrm{FW}$ ) } & \multicolumn{4}{|c|}{ Relative abundance (\%) } \\
\hline & & Os & $\mathrm{Co}$ & $\mathrm{Pl}$ & $\mathrm{Cs}$ & Os & $\mathrm{Co}$ & $\mathrm{Pl}$ & $\mathrm{Cs}$ \\
\hline \multicolumn{10}{|c|}{ Catalonia, summer 1997 and 1998} \\
\hline \multicolumn{10}{|l|}{ Phaeophyceae } \\
\hline Dictyota dichotoma & 1 & 312 & 37 & 73 & 0 & 74 & 9 & 17 & 0 \\
\hline Dictyota dichotoma & 2 & 228 & 2151 & 554 & 196 & 7 & 69 & 18 & 6 \\
\hline Halopteris scoparia & 2 & 0 & 63 & 98 & 0 & 0 & 39 & 61 & 0 \\
\hline Dilophus fasciola & 3 & 414 & 61 & 97 & 170 & 56 & 8 & 13 & 23 \\
\hline Halopteris scoparia & 3 & 10 & 10 & 105 & 0 & 8 & 8 & 85 & 0 \\
\hline Halopteris scoparia & 4 & 0 & 0 & 0 & 1 & 0 & 0 & 0 & 100 \\
\hline Dictyota dichotoma & 5 & 0 & 104 & 367 & 389 & 0 & 12 & 43 & 45 \\
\hline Dictyota dichotoma & 6 & 17939 & 76 & 284 & 132 & 97 & 0 & 2 & 1 \\
\hline Halopteris scoparia & 6 & 7 & 0 & 20 & 0 & 25 & 0 & 75 & 0 \\
\hline Dictyota dichotoma & 8 & 159 & 26 & 53 & 160 & 40 & 7 & 13 & 40 \\
\hline Halopteris scoparia & 8 & 282 & 0 & 311 & 256 & 33 & 0 & 37 & 30 \\
\hline Dilophus fasciola & 9 & 0 & 342 & 683 & 506 & 0 & 22 & 45 & 33 \\
\hline Dilophus fasciola & 10 & 10917 & 363 & 60 & 30 & 96 & 3 & 1 & 0 \\
\hline Dictyota dichotoma & 11 & 21 & 10 & 7573 & 2195 & 0 & 0 & 77 & 22 \\
\hline Halopteris scoparia & 11 & 129 & 39 & 741 & 107 & 13 & 4 & 73 & 11 \\
\hline Dictyota dichotoma & 12 & 0 & 40 & 71 & 0 & 0 & 36 & 64 & 0 \\
\hline Dictyota dichotoma & 13 & 6 & 18 & 0 & 0 & 26 & 74 & 0 & 0 \\
\hline Dictyota dichotoma & 14 & 0 & 0 & 0 & 0 & 0 & 0 & 0 & 0 \\
\hline \multicolumn{10}{|l|}{ Rhodophyta } \\
\hline Corallina elongata & 1 & 0 & 0 & 7 & 0 & 0 & 0 & 100 & 0 \\
\hline Corallina elongata & 2 & 4 & 59 & 28 & 4 & 4 & 63 & 29 & 4 \\
\hline Corallina elongata & 3 & 25 & 18 & 55 & 0 & 25 & 19 & 56 & 0 \\
\hline Corallina elongata & 4 & 0 & 36 & 7 & 58 & 0 & 36 & 7 & 57 \\
\hline Corallina elongata & 5 & 0 & 0 & 2 & 1 & 11 & 0 & 56 & 33 \\
\hline Corallina elongata & 6 & 77136 & 1322 & 1542 & 331 & 96 & 2 & 2 & 0 \\
\hline Jania + Corallina & 9 & 24 & 416 & 559 & 309 & 2 & 32 & 43 & 24 \\
\hline Jania corniculata & 10 & 6543 & 239 & 84 & 6 & 95 & 3 & 1 & 0 \\
\hline Corallina elongata & 11 & 1090 & 88 & 651 & 158 & 55 & 4 & 33 & 8 \\
\hline Corallina elongata & 12 & 0 & 3 & 0 & 0 & 0 & 100 & 0 & 0 \\
\hline Corallina elongata & 14 & 103 & 0 & 6 & 0 & 94 & 0 & 6 & 0 \\
\hline \multicolumn{10}{|l|}{ Majorca, summer 2000} \\
\hline \multicolumn{10}{|l|}{ Phaeophyceae } \\
\hline Halopteris scoparia & 15 & - & - & + & ++ & & & & \\
\hline Dictyopteris membranacea & 15 & ++++ & ++ & + & + & & & & \\
\hline Dilophus fasciola & 15 & +++ & ++ & ++ & - & & & & \\
\hline Padina pavonica & 15 & ++++ & ++ & ++ & ++ & & & & \\
\hline Halopteris scoparia & 16 & +++ & - & + & ++++ & & & & \\
\hline Halopteris scoparia & 17 & - & - & + & - & & & & \\
\hline Dictyota + Dilophus & 17 & ++ & + & + & + & & & & \\
\hline \multicolumn{10}{|l|}{ Corsica, summer 1998} \\
\hline \multicolumn{6}{|l|}{ Phaeophyceae + Rhodophyta } & \multicolumn{4}{|c|}{ Other diatoms* } \\
\hline $\begin{array}{l}\text { Mixed sample } \\
\text { (Corallina, Jania, Dictyota, }\end{array}$ & 18 & ++ & - & - & - & ++++ & & & \\
\hline
\end{tabular}


Oxyrrhis marina and Amphidinium sp. in the NW Mediterranean (Vilefranche-sur-Mer). The occurrence of $O$. ovata in the water column was also documented in the Thyrrhenian Sea (Tognetto et al. 1995). Moreover, low cell concentrations of Ostreopsis cf. siamen-

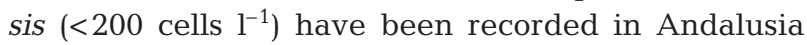
(Mamán et al. 2000) and Catalonia (Vila et al. 2001). An association dominated by C. monotis and low concentrations of Ostreopsis sp. were reported in other Mediterranean localities (Ganzirri Lagoon, Sicily) (Gangemi 2001). However, long-term epiphytic associations had not been quantified in the Mediterranean Sea. In this study, the epiphytic microscopic assemblage mentioned in the previous section was also detected in samples from Majorca and Corsica. Thus, this association is probably common in the NW Mediterranean Sea.

A similar association, consisting of Ostreopsis siamensis, O. lenticularis, O. ovata, Prorocentrum lima, $P$. compressum and Coolia monotis, has been recorded in northern New Zealand. The dominant species, O. siamensis, accounted for 64 to $85 \%$ of the total epiphytic flora during summer (Chang et al. 2000). Although Gambierdiscus toxicus and $O$. lenticularis are co-dominant in many tropical regions (Bagins et al. 1985, Ballantine et al. 1985, Carlson \& Tindall 1985, Gillespie et al. 1985, Bomber \& Aikman 1989), G. toxicus has been recorded only once (and in extremely low concentrations) in northern New Zealand (Chang et al. 2000) and never on the Catalan coast. There may be a latitudinal gradient that implies different species composition within the benthic association. What is certain is that these epiphytic assemblages are not restricted to tropical and subtropical waters but are present in temperate water as well.

The epiphytic and benthic dinoflagellates from New Zealand seem to be associated with the lipid-soluble toxins detected in shellfish from the studied area. However, the link between toxins and the presence of Ostreopsis siamensis is not yet clear (Chang et al. 2000). The epiphytic community toxicity in Catalonia had been tested by injecting the extract (intraperitoneally) into mice (modified from the Association of Official Analytic Chemists 1980, Yasumoto et al. 1980). The organic fraction was not toxic, whereas the watersoluble fraction killed the mice in $20 \mathrm{~min}$. The symptoms observed in mice were not PSP symptoms. Instead, they were reminiscent of neurotoxic symptoms (E. Cacho pers. comm.). Signs of paralytic shellfish poisoning (PSP) were also not detected by HPLC analysis (J. M. Franco pers. comm.). Our preliminary results suggest that the toxin is present in the watersoluble fraction, in disagreement with the study carried out in New Zealand and in agreement with Tindall et al. (1990), who identified a water-soluble toxin very similar to maitotoxin (ostreotoxin) in O. lenticularis. However, the specific toxicity of the Mediterranean epiphytic community requires further research.

\section{Preferred habitat and seasonal variability}

Dinoflagellates in this study were epiphytic on macroalgae, and low densities were detected in the water column and on the sediments. Numerous species of macroalgae host significant numbers of epiphytic dinoflagellates. They include members of Rodophyta, Phaeophyta, Chlorophyta and Cyanophyta (Tindall \& Morton 1998). The macroalgae tested in this study, which correspond mainly to Rodophyta and Phaeophyta, supported high densities of epiphytic dinoflagellates. The highest density detected for Ostreopsis sp. in this study was $5.9 \times 10^{5}$ cells $\mathrm{g}^{-1} \mathrm{FW}$ in Halopteris scoparia during July 1997. To our knowledge, this is one of the highest densities of epiphytic species ever reported. For example, the highest density of Ostreopsis lenticularis was estimated to be $2.35 \times 10^{5}$ cells g $^{-1}$ FW on the macroalga Dictyota at Laurel Reef, Puerto Rico (Ballantine et al. 1985) and that of Gambierdiscus toxicus was estimated to be $5.0 \times 10^{5}$ cells g $^{-1} \mathrm{FW}$ on Jania in a Gambier Island reef (Yasumoto et al. 1980). At Virgin Islands, Coolia monotis density was $1.2 \times 10^{6}$ cells $\mathrm{g}^{-1} \mathrm{FW}$ macroalgae and that of Prorocentrum mexicanum was $1.5 \times 10^{6}$ cells $\mathrm{g}^{-1} \mathrm{FW}$ macroalgae (Carlson \& Tindall 1985). However, the maximum densities of epiphytic species commonly range from $10^{2}$ to $10^{4}$ cells g ${ }^{-1} \mathrm{FW}$ macroalgae (Tindall \& Morton 1998). Significant differences in epiphytic densities between macroalgae were not detected in this study, in agreement with Taylor (1985), Lobel et al. (1988) and Bomber et al. (1989), who stated that epiphytic dinoflagellates prefer 3-dimensional, flexible, high-surface area algae, like the macroalgae sampled in this study, rather than a particular macroalgal species or phylum.

Cell densities around $10 \times 10^{3}$ to $20 \times 10^{3}$ cell $^{-1}$ were sometimes recorded during warm months in the water column at the sampling site (Stn 7). However, bloom concentrations of Ostreopsis were never detected in the water column and Ostreopsis was very scarce on the sediment. The positive and significant correlation of Ostreopsis sp. concentrations in the water column and sediment with those on macroalgae probably indicates that the former were resuspended or released from the surface of macroalgae. The presence of Ostreopsis sp. in the water column on the Catalan coast has been well documented since the beginning of routine monitoring in 1995 (Vila et al. 2001). Ostreopsis sp. in the water column has occasionally been detected, but in cell densities lower than 100 cells $^{-1}$. High densities of Ostreopsis sp. were observed only in Garraf harbour 


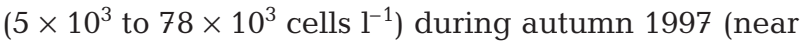
Stn 13), concomitant with wrested macroalgae that were floating during the sampling days, and in Blanes harbour $\left(98 \times 10^{3}\right.$ cells $\left.^{-1}\right)$ on October 27, 1997 (near Stn 10), after a heavy storm. Thus, the preferred habitat of Ostreopsis sp. in the Catalan sea is epiphytic on macroalgae. In coral reef areas, these organisms were mostly associated with macroalgae located between 0.5 and $3 \mathrm{~m}$ (Ballantine et al. 1985, Carlson \& Tindall 1985, Bomber \& Aikman 1989), but macroalgae attached to mangrove roots and dead coral pavement did not support high numbers of dinoflagellates (Carlson \& Tindall 1985). In contrast, dead corals colonised by algal turf to various extents had higher epiphytic dinoflagellate densities than macroalgal substrates in Mayotte Island (SW Indian Ocean) (Grzebyk et al. 1994, Quod 1994).

The dinoflagellate assemblage on macroalgae follows a clear seasonal pattern in response to several factors, probably the same factors that trigger spring growth of macroalgae in the area (Ballesteros 1992): increase in temperature and irradiance at the beginning of spring, calmer sea (the spatial variability due to hydrodynamic regimens is significant) and availability of substrate. No significant correlations were observed between epiphytic organisms and water temperature or nutrients. Gillespie et al. (1985) showed that periodicity in the densities of Gambierdiscus toxicus was not directly linked to temperature. They found the maximum density in water at temperatures near $20^{\circ} \mathrm{C}$ and before the maximum temperature was reached. Here, no clear seasonal pattern in the relative abundance of epiphytic organisms was observed (e.g., substitution of dinoflagellates vs diatoms). The dominant dinoflagellate was mostly Ostreopsis sp., although Coolia monotis and Prorocentrum lima occasionally achieved high absolute and relative numbers. The mechanisms that trigger species abundance are unclear, but changes in the hydrodynamic regime many be involved. Spatial variability (Fig. 5) indicates that although C. monotis and Ostreopsis sp. are better adapted to slightly shaken environments, C. monotis outnumbers Ostreopsis sp. in calm waters; however, the former is excluded by Ostreopsis sp. in shaken waters.

In autumn, the input of external energy from storms and rains exerts a negative effect on the macroalgae, which simplify the macroalgal community structure and reduce the biomass (Ballesteros 1992). These conditions may also affect all epiphytic organisms. Differences in cell concentration during warm and cold months may also result from the carrying capacity of macroalgae (Lobel et al. 1988), which varies according to hydrodynamic characteristics (Tindall \& Morton 1998). Each species of macroalga has a characteristic surface area or space, which, once occupied, can sup- port no additional cells. In high turbulence conditions, this space is limited to the surface layer, whereas in stagnant conditions dinoflagellates multiply to fill all the spaces within the macroalgal canopy. In highly turbulent conditions, when no additional cells can be supported by macroalgae, dinoflagellates continuously migrate to adjacent areas. Bomber et al. (1989) suggested that the presence of Prorocentrum spp., Coolia monotis and Ostreopsis siamensis in the water column is due to vertical migration, which facilitates cell redistribution and concentration. Thus, the epiflora does not strictly depend on a given macroalga because under certain circumstances (e.g., macroalga death) they can migrate and colonise other algae.

The high cell concentrations recorded during summer for the 4 target macroalgae are attributed to the less shaken and more stable water environments, similar to the Type II system described by Tindall \& Morton (1998). On the other hand, the low cell concentrations recorded during winter months, which are probably associated with more shaken fluxes, can be compared to the Type I system.

In conclusion, the epiphytic associations of Ostreopsis sp., Coolia monotis, Prorocentrum lima and Coscinodiscus sp. are characteristic along the Catalan coast, NW Mediterranean. Further research in other areas of the Mediterranean Sea is required to define the spatial distribution and to determine whether such an association exists.

Acknowledgements. We thank M. Delgado, E. Ballesteros and collaborators for sampling assistance, E. Ballesteros for the taxonomical identification of macroalgae, S. Fraga for comments and suggestions on scanning electron microscopy protocols and Ostreopsis taxonomy, and E. Cacho and J. M. Franco for toxicity analysis. J. M. Fortuño, R. Fernández and R. Ventosa provided technical assistance. The authors thank J. Camp for critical reading of the manuscript and his support of our work. Financial support was provided by the ACA (Departament de Medi Ambient, Generalitat de Catalunya) and CSIC.

\section{LITERATURE CITED}

Adachi R, Fukuyo Y (1979) The thecal structure of a marine toxic dinoflagellate Gambierdiscus toxicus gen. et sp. nov. collected in a ciguatera-endemic area. Bull Jpn Soc Sci Fish 45:67-71

Association of Official Analytic Chemists (1980) Standard mouse bioassay for paralytic shellfish toxins. In: Horwitz W (ed) Official methods of analysis, 13th edn. Association of Official Analytic Chemists, Washington, p 298-299

Bagins R, Bennet J, Prieur C, Legrand AM (1985) The dynamics of three toxic benthic dinoflagellates and the toxicity of ciguateric surgeonfish in French Polynesia. In: Anderson DM, White AW, Baden DG (eds) Toxic dinoflagellates. Elsevier Science Publisher, New York, p 177-182

Ballantine DL, Bardales AT, Tosteson TR, Durst HD (1985) Seasonal abundance of Gambierdiscus toxicus and Ostre- 
opsis sp. in coastal waters of southwest Puerto Rico. Proc 5th Int Coral Reef Congress, Tahiti 4:417-422

Ballesteros E (1992) Els vegetals i la zonació litoral: espècies, comunitats i factors que influeixen en la seva distribució. Institut d'Estudis Catalans, Barcelona

Bomber JW, Aikman KE (1989) The ciguatera dinoflagellates. Biol Oceanogr 6:291-311

Bomber JW, Rubio MG, Norris DR (1989) Epiphytism of dinoflagellates associated with ciguatera: substrate specificity and nutrition. Phycologia 28:360-368

Bourdeau P, Durand-Clement M, Ammar M, Fessard V (1995) Ecological and toxicological characteristics of benthic dinoflagellates in a ciguateric area (Saint Barthelemy: French West Indies). In: Lassus P, Arzul G, Erard E, Gentien P, Marcaillou C (eds) Harmful marine algal blooms. Lavoisier, London, p 133-137

Carlson RD, Tindall DR (1985) Distribution and periodicity of toxic dinoflagellates in the Virgin Islands. In: Anderson DM, White AW, Baden DG (eds) Toxic dinoflagellates. Elsevier, New York, p 171-176

Chang FH, Shimizu Y, Hay B, Stewart R, Mackay G, Tasker R (2000) Three recently recorded Ostreopsis spp. (Dinophyceae) in New Zealand: temporal and regional distribution in the upper North Island from 1995 to 1997. NZ J Mar Freshw Res 34(1):29-39

Faust MA (1995) Benthic, toxic dinoflagellates: an overview. In: Lassus P, Arzul G, Erard E, Gentien P, Marcaillou C (eds) Harmful marine algal blooms. Lavoisier, London, p 847-854

Faust MA (1999) Three new Ostreopsis species (Dinophyceae): O.marinus sp. nov., O. belizeanus sp. nov., and O. carribeanus sp. nov. Phycologia 38(2):92-99

Faust MA, Morton SL (1995) Morphology and ecology of the marine dinoflagellate Ostreopsis labens sp. nov. (Dinophyceae). J Phycol 31:456-463

Faust MA, Morton SL, Quod JP (1996) Further SEM study of marine dinoflagellates: the genus Ostreopsis (Dinophyceae). J Phycol 32:1053-1065

Fukuyo Y (1981) Taxonomical study on benthic dinoflagellates collected in Coral Reefs. Bull Jpn Soc Sci Fish 47(8): 967-978

Gangemi E (2001) Dinoflagellati nocivi nelle fitocenosi di un ecosistema litorale della Sicilia Orientale (Pantano Grande-Lagune di Capo Peloro, Me). PhD thesis, Università di Messina, Sicily

Gillespie NC, Holmes MJ, Burke JB, Doley J (1985) Distribution and periodicity of Gambierdiscus toxicus in Queensland, Australia. In: Anderson DM, White AW, Baden DG (eds) Toxic dinoflagellates. Elsevier, New York, p 183-188

Grasshoff K, Ehrhardt M, Kremling K (1983) Methods of sea water analysis. Ed Verlag Chemie, Weinheim

Grzebyk D, Berland B, Thomassin BA, Bossi C, Arnoux A (1994) Ecology of ciguateric dinoflagellates in the coral reef complex of Maynotte Island (S.W. Indian Ocean). J Exp Mar Biol Ecol 178:51-66

Lobel PS, Anderson DM, Durand-Clement M (1988) Assessment of ciguatera dinoflagellate populations: sample variability and algal substrate selection. Biol Bull 175:91-101

Mamán L, Fernández L, Ocaña A, Marco JJ, Morales J, Caballos M, Márquez I, Aguilar M (2000) Seguimiento de fitoplancton tóxico en la costa de Andalucía durante los años 1997 y 1998. In: Márquez I (ed) VI Reunión Ibérica de Fitoplancton Tóxico y Biotoxinas Sevilla, Junta de Andalucía, p 41-49

Editorial responsibility: David Caron,

Los Angeles, California, USA
Nakajima I, Oshima Y, Yasumoto T (1981) Toxicity of benthic dinoflagellates in Okinawa. Bull Jpn Soc Sci Fish 47: 1029-1033

Norris DR, Bomber JW, Balech E (1985) Benthic dinoflagellates associated with ciguatera from Florida Keys. I. Ostreopsis heptagona sp. nov. In: Anderson DM, White AW, Baden DG (eds) Toxic dinoflagellates. Elsevier, New York, p 39-44

Penna A, Gangemi E, Vila M, Giacobbe MG, Garcés E, Florean $\mathrm{S}$, Androni $\mathrm{F}$, Magnani $\mathrm{M}$ (in press) A preliminary survey of Ostreopsidaceae (Dinophyta) in the Mediterannean: molecular and morphological analyses of different isolates. Phycologia 40(Suppl):51

Quod JP (1994) Ostreopsis mascarensis sp. nov. (Dinophyceae), dinoflagellé toxique associé à la ciguatera dans l'Océan Indien. Cryptogamie. Algol 15(4):243-251

Schmidt J (1902) Flora of Koh Chang. Contritution to the knowledge of the vegetation in the Gulf of Siam. Part IV. Peridiniales. J Bot 23:212-218

Steidinger KA (1983) A re-evaluation of toxic dinoflagellate biology and ecology. In: Round FE, Chapman D (ed) Progress in phycological research. New York, Elsevier, p 147-188

Steidinger KA, Baden DG (1984) Toxic marine dinoflagellates. In: Spectot DL (ed) Dinoflagellates. Academic Press, New York, p 201-261

Taylor FJR (1979) A description of the benthic dinoflagellate associated with maitotoxin and ciguatoxin, including observations on Hawaiian material. In: Taylor DL, Seliger $\mathrm{HH}$ (eds) Toxic dinoflagellate blooms. Elsevier North Holland, New York, p 71-76

Taylor JFR (1985) The distribution of the dinoflagellate Gambierdiscus toxicus in eastern Caribbean. In: Salvat B (ed) Proc 5th Int Coral Reef Congress, Moorea, p 423-428

Throndsen J (1995) Estimating cell numbers. In: Hallegraeff GM, Anderson DM, Cembella AD (eds) Manual on harmful marine microalgae. IOC Manuals and Guides No. 33. UNESCO, Paris, p 63-80

Tindall DR, Miller DM, Tindall PM (1990) Toxicity of Ostreopsis lenticularis from the British and United States Virgin Islands. In: Graneli E, Sundström B, Edler L, Anderson DM (eds) Toxic marine phytoplankton. Elsevier, New York, p 424-429

Tindall DR, Morton SL (1998) Community dynamics and physiology of epiphytic/benthic dinoflagellates associated with Ciguatera. In: Anderson DA, Cembella AD, Hallegraeff GM (eds) Physiological ecology of harmful algal blooms. Springer-Verlag, Berlin, p 293-313

Tognetto L, Bellato S, Moro I, Andreoli C (1995) Occurrence of Ostreopsis ovata (Dinophyceae) in the Tyrrhenian Sea during summer 1994. Bot Mar 38:291-295

Vila M, Camp J, Garcés E, Masó M, Delgado M (2001) High resolution spatio-temporal detection of HABs in confined waters of the NW Mediterranean. J Plankton Res 23(5): 497-514

Yasumoto T, Nakajima I, Bagins R, Adachi R (1977) Finding of a dinoflagellate as a likely culprit of ciguatera. Bull Jpn Soc Sci Fish 43:1021-26

Yasumoto T, Oshima Y, Murakami Y, Nakajima I, Bagnis R, Fukuyo Y (1980) Toxicity of benthic dinoflagellates found in coral reef. Bull Jpn Soc Sci Fish 46(1):327-331

Yasumoto T, Seino N, Murakami Y, Muata M (1987) Toxins produced by benthic dinoflagellates. Biol Bull 172: 128-131

Submitted: April 18, 2001; Accepted: July 16, 2001

Proofs received from author(s): October 17, 2001 